\title{
Analysis of the Innovation Personality Cultivation of the Innovative Entrepreneurship Education in Colleges and Universities
}

\author{
Jun Wang \\ Department of Ideological and political education, Xijing University, Xi'an, Shaanxi 710123, China \\ wangjun2891@163.com
}

Keywords: Colleges and universities; Innovative personality; Culture; Innovation entrepreneurship education

\begin{abstract}
With the quality-oriented education's development, pay more attention to cultivation students' creative personality in classroom. At present, the innovation of entrepreneurship education in colleges and universities is a kind of different education from the traditional one, it is a kind of student-centered teaching activity, it is a kind of teaching mode about how to improve the students' innovation personality, so as to let the students in the classroom active status, therefore, when teaching knowledge in the classroom, it is more likely to achieve students subjective initiative into full play. As innovation entrepreneurship education personnel in colleges and universities, we should fully realized that the cultivation of innovative personality can bring effect for innovation entrepreneurship education classroom teaching, it can develop students' potential ability, letting the students in innovative entrepreneurship education classroom demonstrate their creative ability so as to improve teaching effectiveness.
\end{abstract}

\section{Introduction}

The teaching concept which in order to improve the students' innovative personality is a kind of teaching model based on innovation entrepreneurship education, in classroom teaching, all the teaching methods are around the students, students play an active role in the classroom, it can increase the interaction between teachers and students. In the teaching process, however, some problems still exist, as teachers, we must actively deal with problems and find the corresponding solution, gradually improve innovation entrepreneurship education.

\section{Realize the Important Significance of Innovative Personality Cultivation for the Development of Innovation Entrepreneurship Education}

The innovation entrepreneurship education in colleges and universities is to cultivate all-round comprehensive high quality talents which have the capacity of innovation and entrepreneurship, thus requires the teachers in class should fully mobilize students' learning enthusiasm and change the traditional boring classroom teaching atmosphere, let the student study in the harmonious teaching atmosphere and master the fundamental creative education, cultivating students' innovative personality. Students from passive ones to active ones, it is helpful for improving the efficiency of classroom teaching and conducive to the development of students' creative thinking, students really have innovative personality the consciousness of independent innovation, the innovation of entrepreneurship education in colleges and universities also becomes simple and easy. Students in the classroom communicate and discuss with teachers freely, teachers encourage students to explore and give full play to their dominant position, learning effects is improved naturally.

\section{The Problems and Solutions for Cultivating Innovation Personality in Entrepreneurship Education in Colleges and Universities}

First, the teaching way is conformism. Many teachers in the institutions of higher learning innovation entrepreneurship education make innovations in entrepreneurship education in the process of classroom teaching, is not willing to abandon the old teaching ideas, still follows the old 
exam-oriented education rules, it brings resistance for cultivating comprehensive talents with high quality, it is not conducive to cultivate high-quality talents with innovative personality. To improve the students' ability of practice and application, In order to cultivate innovative personality, we must attach importance to the cultivation of the students learning methods, attaches great importance to promote the students' abilities such as put forward questions by students themselves, independent analysis problem, the ability to solve the problem actively. Continuously summarize study methods and apply what they have learned in the class to the outside the classroom. In the process of innovation entrepreneurship education, students in the dominant position can improve the students' interest in learning and let the students can actively participate in classroom. The positive interaction of teaching atmosphere can help the student to master good habits of innovation and improve the classroom efficiency and can lay a solid foundation for entrepreneurial road in the future.

Second, the creative education in colleges and universities don't pay attention to connection between the textbook knowledge with the actual situation. The classroom teaching of innovation entrepreneurship education in colleges and universities, teachers often only teach material content, however, the knowledge of innovation entrepreneurship can only cope with exams and is not conducive to improving the students' learning interest, teaching theory already satisfy the students' learning desire and exploring spirit.

Only teaching the material knowledge cultivates students' inner innovation personality. Materials only attach more importance to the interpretation of knowledge for exam, teachers should also choose life common examples in class to link with the textbook knowledge, it is beneficial to the cultivation of the students' active learning spirit, college students thoughts are "active", let them feel creative knowledge can not only be applied to the test, and also is indispensable in daily life, in this way, they gradually use the theoretical knowledge of textbook for entrepreneurship practice, it would be easier to stimulate students' active learning spirit and learning interest will be improved, it is more conducive to cultivating students' creative personality.

\section{How to Improve the Effectiveness of Cultivating Students' Innovative Personality}

First, the innovative entrepreneurship education teachers in colleges and universities should learn how to stimulate students' imagination and creativity. Innovation entrepreneurship education as an important component part of the education reform practice in colleges and universities at present. Not only the rigid knowledge in the textbook, innovation entrepreneurship education has infinite charm, teachers teach students' innovative entrepreneurial knowledge, at the same time, teachers should let the students feel the endless charm that innovation entrepreneurship education bring to us, in the learning process ,changing the innovative entrepreneurship from a simple literacy course into a utilization rate is extremely play high application role in daily life, in this way, students' learning attitude will fundamentally change, learning interest is to get the corresponding ascension, the cultivation of innovative personality would be much easier.

Second, a harmonious relationship between teachers and students. Entrepreneurship education is in order to cultivate students' innovative personality in colleges and universities, in the process of transformation from the traditional teaching mode to the student-centered teaching mode, the relationship between the students and teachers also take place some subtle changes, in the classroom, we must pay attention to equality and democracy relation between teachers and students, good rapport, classroom learning atmosphere becomes relaxed and happy, in the cultivation of innovative personality becomes not so boring. To make the students interested in innovation of entrepreneurship learning, confidence in mastering innovation entrepreneurship. Enriched the teaching links, students participate more in the activities, learning content become more unforgettable, in this way, from passive rote memorization to active study way. Students want to learn, willing to learn, achieve the goal of combining the teaching with fun, insisting for a long time, students will interested in entrepreneurship education curriculum and can achieve the cultivation of students' innovative personality.

Third, increase the students' time under the guidance of innovative entrepreneurship education. The teaching methods for the purpose of cultivating students' innovative personality, we must ensure 
students' hands-on practice time, time is limited in class, the teacher said more time, the less students can get the chance to exercise, improve the teaching quality of innovative personality cultivation, improve the students' mastery of creative knowledge level, promote the students' love of innovation entrepreneurship courses, entrepreneurship education requires teachers only do inspired students, encouraging students to actively take part in discussion, teachers teach students the innovation knowledge which is necessary for students' communication, don't take up a lot of classroom time. Let students make clear the task and method, the teacher can let students to communicate knowledge, so as to achieve the subject status of students in the classroom and to cultivate students' innovative personality.

\section{Innovation Education, must Take the Student as the Guidance, to Cultivate Students' Innovative Personality}

First, the teacher must learn to motivate the students' imagination and creativity. Innovative entrepreneurship education as important reform factors in the process of the present quality education practice, is not just a textbook rigid formula and the knowledge of science and technology, innovation entrepreneurship education has infinite charm, teachers teaching the students' innovative entrepreneurial knowledge, at the same time also, teachers should let students feel the importance of innovation education for future entering society and innovation personality charm, entrepreneurship education from the course into an essential practical knowledge in daily life in the process of learning, in this way, students' innovative entrepreneurial learning attitude will change radically. Innovative personality is a key part in the process of innovation main body qualities of innovative talents, and not just a purely intellectual activities, it is a kind of personality on the basis of innovation, innovation, driven the integration of building process. Driven by a strong emotion, students can give full play to their talents, and constantly release of energy and enthusiasm, innovative learning. Innovation personality and emotion can promote social progress and the noble and unique goals, choosing to save the infinite innovation momentum conservation, the challenge of their maintenance, climbing, dare to make full use of the entrepreneurial style, maintenance, in order to improve the aesthetic value of noble sentiment of life, maintenance for the human struggle, to optimize the quality, the pursuit of personal excellence, strive and practice, seriously to master modern technology, saving time, the enthusiasm of the new channels, to create a bold, brave to the reform of knowledge. Good quality of thinking is the core of the creative activities, students can make use of abstract thinking and creative thinking of image capture and enlarge freedom of thought; Get rid of the mindset, advocate, on the basis of reverse thinking, release the passion of innovation, create new and original, the results of thinking, social significance. With the development of the society, innovation has become an important factor in the development of colleges and universities.

\section{The Method of Using Cooperative Learning to Promote Education Results in the Personality Cultivation of Innovation Entrepreneurship Education}

Innovation entrepreneurship education practice in colleges and universities use the concept of student-oriented implementation implement, we must maximize lets the student participate in exploring, through the way of cooperative learning group, developing and strengthening the cultivation of students innovative thinking ability, in the process of cooperation to explore communication, students through the show and the form of speech to communicate, form a resource sharing is helpful to display their own ideas and helpful to fully understand the teaching content, in the process of cooperation explore, promote each other and learn from each other between the students are more likely to promote the development of inquiry ability. Therefore, cooperative learning for inquiry learning has a positive role in promoting, promoting the results of exploratory learning, it is helpful for cultivating students' innovative personality.

Using multimedia teaching to promote innovative entrepreneurship education in colleges and universities for shaping students' innovation personality. Under the background of the concepts, innovative entrepreneurship education in colleges and universities can supplement teaching with the 
help of multimedia courseware, make full use of the advantages of multimedia, teachers can according to the different creative teaching goal, according to the development of the students' ability to make courseware, it is advantageous to the student independent thinking and communication, through the auxiliary courseware, the efficiency of the class will be greatly improved, the students' innovative personality will get the corresponding shape.

\section{Key Points of Innovation and Entrepreneurship Education}

Under the concept of innovation, in the process of entrepreneurship education in colleges and universities, teachers must make students to learn themselves and explore, give full play to the dominant position of students in the classroom, teachers only guide the students before class, let the students find misunderstanding knowledge points in the process of making a summary and putting forward the question. For most of the problems, students can solve the problem by means of fully exercise the students' ability of solving the problem. For those problems which can't solve through making a summary of these problems, reporting to the teachers, teachers in the process of reentry guidance can deepen students' impression in order to achieve better learning effect. Planning the teaching and study process, in this way, students ability can get plenty of exercise in the class, the teacher can also found key points in classroom teaching according to the results of the students' . Teaching and learning is more targeted, teaching effectiveness has got corresponding improvement. Only in this way, it can fully cultivate students' innovative personality in the process of entrepreneurship education practice.

\section{Conclusion}

Above all, in the process of innovation entrepreneurship education of the higher learning institutions, letting the students at the center of the classroom, making them become the master of the classroom, student positive to learn classroom knowledge and do inquisitive learning. the good habit of solving problems by themselves, it will make the students' innovative spirit, entrepreneurial spirit and innovation consciousness improved fully, therefore, it will play a promoting role in the shaping of innovative personality. Teachers of innovation entrepreneurship education in colleges and universities need to do is to inspire students' independent learning potential in the classroom, strive to be a qualified guide to motivate students and evaluate students, letting the students have the opportunity to make decision for their class. In the process of entrepreneurship education in colleges and universities should make students from passive to accept knowledge into active explore the charm of knowledge, play students' subjective initiative, which requires the personnel of innovation of entrepreneurship education in colleges and universities considering the present situation and the needs of students, Combining the teaching activities with students' real life closely according to various characteristics of different students, the age characteristics of junior high school students and emotional characteristics, based on the "for the purpose of the development of students, student needs-oriented", realize their aptitude. Only in this way can improve the teaching effect in teaching practice, it is more advantageous to achieve the teaching purpose and cultivate students' innovative personality.

\section{References}

[1] Theory innovation entrepreneurship education into the university personnel training system of the implementation of the approachHu GuangzhongLiu Xiangli- The journal of jiangxi institute education - 2011 .

[2] Introduction to several misunderstandings of the creative education in colleges and universities Chen Jiashu - The china-asean expo - 2013.

[3] Analysis of humanistic quality education of the creative education in colleges and universitiesChen Chi - The Chinese market - 2015. 
[4] Analyses the role of ideological and political education to cultivate college students' innovative personality, Zhang HongxinZhang Hongwei, Wei Weiwei - A new generation of monthly magazine- 2014.

[5] An analysis on innovation and entrepreneurship education of college students of traditional Chinese medicine -- Taking Shaanxi University of Chinese Medicine as an exampleZhao Xin Hua Zhang- 2014 .

[6] Personality characteristics and cultivation of innovative talentsLi Mingjian - China university of science and technology -2014.

[7] Analysis on the construction of innovation and entrepreneurship education system in Applied Undergraduate Colleges --As CZ college for exampleBai Shaoye - Journal of Jiamusi College of Education - 2014 .

[8] Patriotic education, creative education, personality education-A brief discussion on the reform of the key courses in the history of the UniversityLi WeizhongZhang ZhuangqiangJournal of Yulin Normal University - 2012.

[9] Jingliang - Fudan University press - 2012.

[10] Innovative education in Colleges and Universities, Zhou Yanbo - Science Press - 2011. 